\title{
KEDUDUKAN KOMISI PEMBERANTASAN KORUPSI (KPK) DALAM STRUKTUR KETATANEGARAAN INDONESIA DITINJAU DARI HUKUM ISLAM
}

\author{
Yopa Puspitasari \\ Institut Agama Islam Negeri Bengkulu \\ Jalan Raden Fatah Pagar Dewa Kota Bengkulu \\ Email: yopapuspita234@gmail.com
}

\begin{abstract}
The position of the Corruption Eradication Commission is currently a problem, because its authority is too broad and even exceeds the institutions regulated in the constitution. The Corruption Eradication Commission, is an institution regulated in Law Number 30 of 2002 concerning the Corruption Eradication Commission. In Islamic law itself the institution of the Corruption Eradication Commission is not regulated in a special institution such as in Indonesia, but there is an institution that is almost the same as the Corruption Eradication Commission, namely the Al-Mazalim Region. This research is juridical normati with the primary source is the Law on the Eradication of Corruption Crime and Books relating to the Al-Mazalim Region. The results of the study show that the issue of the position of the Corruption Eradication Commission is regulated in Law No. 30 of 2002, where the Corruption Eradication Commission according to the Act is an independent institution free from the influence of any power. Although the institution of the Corruption Eradication Commission was not the main institution regulated by the 1945 Constitution but the Commission which was regulated by Law, but its position was the same as the institutions stipulated in the 1945 Constitution. ', and al-Hisbah region, namely resolving cases that cannot be resolved by the two judicial institutions, namely the problem of persecution carried out by the authorities, judges, or their families. In addition, the Al-Mazhalim Region is independent with no intervention by the Head of State or State Officials.
\end{abstract}

Keywords: Corruption Eradication Commission; Independent; Al-Mazalim Region.

\begin{abstract}
Abstrak: Kedudukan Komisi Pemberantasan Korupsi saat ini menjadi sebuah permasalahan, lantaran kewenangannya yang terlalu luas bahkan melebihi lembaga-lembaga yang diatur dalam konstitusi. Komisi Pemberantasan Korupsi, merupakan lembaga yang diatur dalam Undang-Undang Nomor 30 Tahun 2002 tentang Komisi Pemberantasan Korupsi. Dalam hukum Islam sendiri, lembaga Komisi Pemberantasan Korupsi tidak diatur dalam lembaga yang khusus seperti di Indonesia, melainkan ada sebuah lembaga yang hampir sama dengan Komisi Pemberantasan Korupsi, yaitu Wilayah Al-Mazalim. Penelitian ini merupakan penelitian Yuridis Normati dengan sumber primernya adalah Undang-Undang Tentang Pemberantasan Tindak Pidana Korupsi dan Buku-Buku yang berhubungan dengan Wilayah Al-Mazalim. Hasil penelitian menunjukan bahwa masalah kedudukan Komisi Pemberantas Korupsi tersebut diatur dalam UU Nomor 30 Tahun 2002, dimana lembaga Komisi Pemberantas Korupsi menurut UU tersebut, merupakan lembaga yang independen yang bebas dari pengaruh kekuasaan manapun. Walaupun lembaga Komisi Pemberantas Korupsi bukan termasuk lembaga utama yang diatur UUD 1945 melainkan Komisi yang diatur UU, namun secara kedudukannya sama dengan lembaga-lembaga yang diatur dalam UUD 1945. Sedangakan Wilayah Al-Mazalim adalah suatu kekuasaan peradilan yang lebih tinggi dari Wilayah al-Qadha', dan Wilayah al-Hisbah, yakni menyelesaikan perkara yang tidak dapat diselesaikan oleh kedua lembaga peradilan tersebut, yaitu masalah penganiayaan yang dilakukan oleh para penguasa, hakim-hakim, atau keluarganya. Selain itu Wilayah Al-Mazhalim bersifat independen yang tidak ada intervensi oleh Kepala Negara atau Pejabat Negara.
\end{abstract}

Kata kunci: Komisi Pemberantasan Korupsi; Independen; Wilayah Al-Mazalim. 
AL-IMARAH: Jurnal Pemerintahan dan Politik Islam

Vol. 4, No. 2, 2019

\section{Pendahuluan}

Setelah amandemen UUD 1945 banyak perubahan dalam sistem Ketatanegaraan Indonesia termasuk nama Lembaga-lembaga Negara. Dimana ada Lembaga Tertinggi Negara dan Lembaga Tinggi Negara. Namun, setelah diamandemenya Konstitusi Negara Indonesia tidak ada lagi sebutan Lembaga Tertinggi atau Lembaga Tinggi, semua disebut Lembaga Negara. Setelah itu, Muncullah lembagalembaga baru di Indonesia baik Lembaga yang diberi kekuasaan oleh UUD 1945, lembaga diberi kekuasaan dari UU, dan lembaga yang dibentuk berdasarkan Keputusan Presiden. ${ }^{1}$

Salah satu lembaga baru yang dibentuk pada era Reformasi di Indonesia adalah Komisi Pemberantasan Korupsi (KPK). Lembaga ini dibentuk sebagai salah satu agenda terpenting dalam pembenahan tata Pemerintah di Indonesia. Berdasarkan hirarki Peraturan Perundang-undangan, maka landasan yuridis pembentukan dan pemberian wewenang merupakan ketentuan Pasal 43 ayat (1) Undang-Undang Nomor 31 Tahun 1999 tentang Tindak Pidana Korupsi, dan melalui Undang-Undang Nomor 30 Tahun 2002 tentang Komisi Pemberantasan Tindak Pidana Korupsi, Komisi ini pun sah didirikan dan

${ }^{1}$ Elwi Danil, KORUPSI: Konsep, Tindak Pidana, Dan Pemberantas, (Jakarta: PT Raja Grapindo Persada, 2012), h. 238 memiliki legitimasi untuk menjalankan tugasnya. $^{2}$

Pada awal pemerintah orde baru, lembaga Komisi Pemberantasan Korupsi sudah dibentuk berdasarkan Keputusan Presiden Nomor 228 Tahun 1967, dinamakan Komisi Empat yang dipimpin oleh Wilopo. Pada Tahun 1977 dibentuk lagi sebuah Tim untuk memberantas Tindak Pidana Korupsi, yang dinamakan Operasi Tertib (Opsti) berdasarkan Instruksi Presiden Nomor 9 Tahun 1977.

Salah satu latar belakang pembentukan badan khusus tersebut, untuk mengatasi masalah pemberantasan tindak pidana korupsi yang belum dilaksanakan secara optimal. Karena, Badan-badan penegak Hukum yang selama ini diserahi tugas dan kewenangan untuk menangani perkara Tindak Pidana Korupsi, belum berfungsi secara efektif. Sementara Tindak Pidana Korupsi itu sendiri, telah sedemikian rupa berlangsung dalam masyarakat secara meluas, sehingga pada akhirnya dirasakan telah melanggar hak-hak sosial dan ekonomi masyarakat, sebagai bagian Hak Asasi Manusia. ${ }^{3}$

Kedudukan Lembaga Komisi Pemberantas Korupsi (KPK) diatur dalam Undang-Undang Nomor 30 Tahun 2002.

${ }^{2}$ Jimlly Asshiddiqie. Perkembangan Dan Konsolidasi Lembaga Negara Pasca Reformasi. (Jakarta: Sekretariatan Jendral dan Kepaniteraan Mahkamah Konstitusi RI, 2006), h. 42

${ }^{3}$ Elwi Danil, .KORUPSI: Konsep, Tindak Pidana, Dan Pemberantas,... h. 219-220 
Tetapi mengalami banyak hambatan dari kritik element tentang indikasi tebang pilih dalam menangani perkara Korupsi, dan upaya judicial review terhadap Undang-undang Nomor 30 Tahun 2002. Selain itu banyak pendapat dari kalangan masyarakat atau pendapat para pakar-pakar hukum tentang setatus kedudukan Komisi Pemberantasan Korupsi, diantaranya polemiki apakah Komisi Pemberantas Korupsi bagian eksekutif atau yudikatif. Sedangkan menurut hukum Islam Lembaga Independen seperti Komisi Pemberantas Korupsi tidak ditemukan, tetapi secara esensi sekilas tugas dan wewenang yang dimiliki Wilayah Mazhalim, hampir ada kemiripan dengan Komisi Pemberantas Korupsi. Oleh karena itulah tulisan ini ingin memperjelas kedudukan lembaga Komisi Pemberantasan Korupsi dalam sistem ketatanegaraan Indonesia dan hubungannya dengan Hukum Islam.

\section{A. Kajian Teori tentang Lembaga Negara dan Sistem Ketatanegaraan Indonesia}

\section{Teori Lembaga Negara}

Lembaga negara dapat berada dirana legislatif, eksekutif, ataupun yang bersifat campuran. Konsepsi tentang lembaga negara ini dalam bahasa belanda bisa disebut staatsorgaan. Dalam bhasa Indonesia hal itu identik dengan Lembaga Negara. Dalam kamus besar bahasa Indonesia (KBBI 1997), kata lembaga diartikan sebagai; asal mula atau bakal (yang akan menjadi sesuatu), bentuk asli (rupa, wujud), acuan atau ikatan, badan atau organisasi bertujuan melakukan penyelidikan keilmuan atau melakukan suatu usaha, dan pola prilaku yang mapan yang terdiri atas interaksi sosial yang berstruktur. ${ }^{4}$

Sedangkan dalam kamus hukum Belanda-Indonesia kata staatsorgaan ini diterjemahkan sebagai alat pelengkap negara. Kamus hukum Fockema Andreae yang diterjemahkan oleh Saleh Adiwinato dkk. Kata organ juga diartika sebagai perlengkapan negara, badan negara, dan alat perlengkapan negara sering kali dipertukaran satu sama lain, menurut Notabaya, sebelum adanya perubaha penyusunan UUD 1945, cenderung konsisten menggunakan istilah badan negara. Untuk maksud yang sama, konstitusi RIS (Republik Indonesia Serikat) tahun 1949 tidak menggunakan istilah lain kecuali alat pelengkap Negara, sedangkan UUD 1945 setelah perubahan keempat (tahun 2002), sebelum masa Reformasi MPR tidak konsisten menggunakan organ negara, badan negara dan lembaga negara.

Dengan demikian, dapat dikatakan bahwa lembaga apa saja yang dibentuk bukan sebagai lembaga masyarakat dapat kita sebut sebagai lembaga negara. Lembaga negara itu

4 Jimlly Asshiddiqe, Perkembangan Dan Konsuldasi Lembaga Negara Pasca Reformasi. (Jakarta: Sekretariat Jendral Dan Kepaniteraan Mahkamah Kosntitusi RI, 2006), h. 31 
dapat berada dalam rana legislatif, eksekutif, yudikatif, ataupun yang bersifat campuran.

\section{Sistem Ketatanegaraan Republik}

\section{Indonesia.}

Indonesia merupakan negara hukum, salah satu ciri negara hukum adalah pembatasan kekuasaan dalam penyelenggara negara. ${ }^{5}$

Setiap negara yang menganut negara hukum memiliki prinsip yaitu, supermasi hukum, persamaan dihadapan hukum, penegakaan hukum dengan cara tidak bertentangan dengan hukum. ${ }^{6}$

Sistem ketatanegaraan Indonesia menurut UUD RI Tahun 1945 amandemen, dengan tujuan untuk menata kesimbngan (check and balances) antara lembaga negara, sehingga tidak terjadi pemusatan kekuasaan pada satu lembaga negara. Dampak dari adanya perubahan UUD RI Tahun 19945 salah satunya adalah adanya perbedaan yang substansial antara kelembagaan negara, salah satunya kedudukan, tugas, wewenang, hubungan dan cara kerja lembaga negara.

\section{B. Kedudukan Komisi Pemberantasan}

\section{Korupsi dalam Sistem Ketatanegaraan}

\section{Indonesia}

Berdasarkan asas negara hukum, bahwa setiap kegiatan negara harus berdasarkan norma yang berlaku, begitupun pembentukan

\footnotetext{
${ }^{5}$ UUD RI Tahun 1945, Pasal 1 (ayat, 3)

${ }^{6}$ http://digilib.uinsby.ac.id/8699/57/Bab\%202.pdf.

Diakses pada hari Rabu, 10 Oktober 2019, Pukul.13.53

Wib

166
}

komisi negara independen yang mempunyai kedudukan sama dengan lembaga negara yang lain. Dalam rangka untuk mewujudkan amanat UUD 1945. Berdasarkan stuffenbau theorie (teori hirarki norma hukum Hans Kelsen), sebagaimana diatur dalam UU No 12 Tahun 2011, hirarki atau tata urutan peraturan perundang-undangan sebagai berikut: ${ }^{7}$

a. Undang-undang Dasar Negara Republik Indonesia Tahun 1945.

b. Ketetapan Majelis Permusyawaratan Rakyat (MPR)

c. Undang-undang/Peraturan Pemerintah Pengganti Undang-undang

d. Peraturan Pemerintah

e. Peraturan Presiden

f. Peraturan Daerah Provinsi

g. Peraturan Daerah Kebupaten/Kota

Berdasarkan hirarki peraturan perundang-undangan diatas, dasar hukum pembentukan atau legitimasi kewenangan komisi negara independen, baik secara konseptual, maupun normatif dapat digolongkan ke dalam tiga kategori, antara lain: ${ }^{8}$

a) Komisi negara independen yang dibentuk berdasarkan konstitusi

7 Berdasarkan Pasal 7, UU Nomor 12 Tahun 2011,"Tentang Pembentukan Peraturan PerundangUndangan"

8 Adri Fernando Roleh, Kedudukan Komisi Pemberantas Korupsi Dalam Sistem Ketatanegaraan Indonesia, Lex Privatum edisi (Volume V/ Nomor 10, Desember 2017), h. 77 
Yopa Puspitasari:

Kedudukan Komisi Pemberantasan Korupsi (KPK) Dalam Struktur Ketatanegaraan Indonesia Ditinjau Dari Hukum Islam

(constitutional organ/constitutionally entrusted power).

b) Komisi negara independen yang dibentuk berdasarkan undang-undang (legislatively entrusted power), terbagi menjadi dua komisi, yaitu constitutional importance (derajat yang sama dengan lembaga negara yang dibentuk melalui konstitusi, guna mewujudkan

democratische rechtsstaat) dan yang tidak,

c) Komisi negara independen yang dibentuk berdasarkan peraturan perundang-undangan lain di bawah undang-undang (presidential policy).

Ada beberapa lembaga bantu yang dibentuk atas dasar hukum yang sama, diantaranya lembaga yang berdiri atas amanat kontitusi, dan yang dibentuk berdasarkan Undang-undangan. Salah satu lembaga yang dibentuk oleh Undang-undangan adalah Komisi Pemberantasan Korupsi (KPK), walaupun bersifat independen dan tidak ada intervensi dari pihak lain, Komisi Pemberantasan Korupsi (KPK) bukan termasuk dalam trias politika, namun tetap bergantung pada kekuasaan Eksekutif dalam masalah organisasi, dan memliki kaitan dengan kekuasaan Yudikatif dalam hal penyidikan dan persidangan perkara kasus tindak pidana korupsi di pengadilan.
Adapun Kedudukan Lembaga Pemberantas Korupsi dalam struktur ketatanegara Indonesia antara lain:

1. Menurut Undang-Undang Nomor 30 Tahun 2002 tentang Komisi Pemberantasan Korupsi.

Komisi Pemberantas Tindak Pidana Korupsi berdasarkan Pasal 2 Undang-Undang Nomor 30 Tahun 2002 tentang Komisi Pemberantas Tindak Pidana Korupsi berbunyi $;$ " " Dengan Undang-undang ini Komisi Pemberantasan Tindak Pidana Korupsi untuk selanjutnya disebut Komisi Pemberantasan Korupsi."

Kemudian dijelaksan dalam pasal (3), yang menyatakan "komisi pemberantasan Korupsi adalah lembaga negara yang melaksanakan tugas dan wewenangnya bersifat independen dan bebas dari kekuasaan manapun.’

Lembaga Negara Independen yang dimaksud dalam UU diatas, merupakan lembaga yang dalam pelaksanaan dan fungsinya tidak menjadi salah satu dari dari tiga lembaga kekuasaan yaitu trias politika. Tetapi, Komisi Pemberantasan Korupsi mempunyai keterkaitan dengan kekuasaan kehakiman, tetapi tidak berada dibawah kekuasaan kehakiman.

$$
\text { Pembentukan lembaga-lembaga }
$$
negara yang bersifat mandiri dan independen

9 UU Nomor 30 Tahun 2002,'Tentang Komisi Pemberantasan Tindak Pidana Korupsi”, 
AL-IMARAH: Jurnal Pemerintahan dan Politik Islam Vol. 4, No. 2, 2019

secara umum disebabkan oleh adannya ketidak percayaan publik terhadap lembaga-lembaga negara yang ada dalam menyelesaikan persoalan ketatanegaraan, karena lembagalembaga yang sudah ada belum bisa memberikan jalan keluar dan menyelesaikan persoalan yang ada ketika tuntutan perubahan dan perbaikan semakin mengemuka seiring dengan berkembangnya paham demokrasi di Indonesia.

Dari tahun 2002 Komisi Pemberantas Korupsi secara resmi merupakan lembaga anti korupsi yang dimiliki Indonesia, berdasarkan UU No.30 Tahun 2002 tentang Komisi Pemberantasan Korupsi ${ }^{10}$.

\section{Komisi Pemberantasan Korupsi}

(KPK) bukanlah lembaga negara. Tetapi KPK adalah Komisi independen yang tugasnya berkaitan dengan Badan Pemeriksa Keuangan (BPK) terutama dalam hal pengelolaan negara tersebut. ${ }^{11}$

Kedudukan lembaga Komisi

Pemberantas Korupsi (KPK) berada di ibukota Negara Indonesia dan di daerah provinsi dibentuk kantor perwakilan serta bertanggung jawab kepada publik atas pelaksanaan tugasnya dan menyampaikan laporan berkala kepada Presiden RI, DPR RI dan Badan Pemerisaan Keuangan (BPK). KPK

${ }^{10}$ Acmad Badjuru, Peran Komisi Pemberantas Korupsi (KPK) Sebagai Lemmbaga Anti Korupsi Di Indonesia, (Semarang: Jurnal Bisnis dan Ekonomi (JBE), Maret 2018), h. 89

${ }^{11}$ Acmad Badjuru, Peran Komisi Pemberantas Korupsi (KPK) Sebagai Lembaga Anti Korupsi Di Indonesia,... h. 237 bertanggung jawab kepada publik sesuai dengan program kerja dan menerbitkan laporan tahunan serta membuka akses informasi kepada publik. ${ }^{12}$

Dasar pembentukan lembaga-lembaga negara bantu, seperti lembaga KPK, dilandasi oleh lima hal penting antara lain: ${ }^{13}$

a. Rendahnya kredibilitas lembagalembaga penegak hukum yang telah ada sebelumnya, akibat adannya bukti danasumsi mengenai tindak pidana korupsi yang telah mengakar dan sulit diberantas.

b. Tidak independennya lembaga penegak hukum yang telah ada, karena dapat dipengaruhi oleh kekuasaan tertentu.

c. Kurang mampunya lembaga-lembaga hukum yang ada, dalam melaksanakan tugas-tugas yang harus dilakukan pada masa transisi menuju demokrasi, baik persoalan internal dan eksternal.

d. Adanya pengaruh global yang membuat kecenderungan beberapa negara untuk membentuk lembaga-lembaga negara tambahan untuk memperbaiki system lembaga yang telah ada.

e. Adanya tekanan dari lembaga-lembaga internasional untuk memenuhi persyaratan menuju demokratisasi,

12 I Nyoman Ngurah Suwarnatha, Penguatan Eksistensi Lembaga Anti Korupsi Pemberantas Korupsi Dalam UUD 1945, (Jurnal Konstitusi, Vol. II, No 1, Denpasar: 2012), h. 29

${ }^{13}$ I Nyoman Ngurah Suwarnatha, Penguatan Eksistensi Lembaga Anti Korupsi Pemberantas Korupsi Dalam UUD 1945, h..35-36 
Yopa Puspitasari: Kedudukan Komisi Pemberantasan Korupsi (KPK) Dalam Struktur Ketatanegaraan Indonesia Ditinjau Dari Hukum Islam

dengan syarat harus membentuk maupun yudikatif, namun justru mempunyai lembaga-lembaga hukum tambahan. fungsi campur sari ketiganya. ${ }^{15}$ Komisi negara Namun, pembentukan lembaga-lembaga independen sering disebut sebagai Independent tersebut harus memiliki dasar pijak supervisory bodies, yaitu lembaga-lembaga yang kuat dan pradigma yang jelas. Negara yang menjalankan fungsi campuran Sehingga dapat membawa manfaat bagi antara "fungsi regulatif", administratif dan kepentingan publik/umum, serta bagi fungsi penghukuman, yang biasanya terpisah, penataan sistem ketatanegaraan maupun sistem penegak hukum.

Komisi Pemberantasan Korupsi (KPK) dibentuk pada tahun 2003, memiliki tugas dan kewenangan untuk melakukan penyidikan dan penuntutan terhadap tindak pidana korupsi. Agar memenuhi tuntutan reformasi untuk melakukan pemberantasan korupsi, dibutuhkan sebuah badan khusus untuk melakukan pemberantasan korupsi yang telah merajalela di semua lapisan masyarakat dan juga lembaga negara Indonesia.

\section{Komisi Pemberantasan Korupsi} merupakan lembaga negara yang bersifat independen, serta bebas dari pengaruh kekuasaan manapun untuk memberantas Tindak Pidana Korupsi. ${ }^{14}$

Menurut Jimly Asshiddiqie, komisi negara independen adalah organ negara (state organs) yang brsifat independen dan berada diluar cabang kekuasaan eksekutif, legislatif

\footnotetext{
14 Sarmadan Pohan, Perbandingan Lembaga Anti Korupsi Di Indonesia Dan Beberapa Negara Dunia, (Jurnal Justitia Vol. 1 No. 03 Agustus 2014). h. 293-294
} namun dilakukan secara bersamaan oleh suatu komisi negara independen. Komisi itu disebut sebagai "self regulatory agencies". ${ }^{16}$

\section{Tugas Komisi Pemberantasan Korupsi} antara lain; Melakukan koordinasi, Supervise, Penyelidikan, penyidikan dan penuntutan, serta melakukan tindakan-tindakan pencegahan dan Melakukan pemantauan (monitoring).

Dalam melaksanakan tugas koordinasi, Komisi Pemberantas Korupsi berwenan

a. Mengkoordinasikan penyelidikan, penyidikan, dan penuntutan tindak pidana korupsi; menetapkan sistem pelaporan dalam kegiatan pemberantasan tindak pidana korupsi;

b. Menetapkan sisitem pelaporan dalam kegiatan pemberantasan tindak pidana korupsi kepada instansi terkait;

15 Denny Indrayana, Negara Antara Ada Dan Tiada Reformasi Hukum Ketatanegaraa, (Jakarta: Kompas, 2008), h. 265-266

${ }^{16}$ Denny Indrayana, Negara Antara Ada Dan Tiada Reformasi Hukum Ketatanegaraa... h. 266 
AL-IMARAH: Jurnal Pemerintahan dan Politik Islam Vol. 4, No. 2, 2019

c. Memintak informasi tentang kegiatan pemberantasan tindak pidana korupsi kepada instasi yang terkait;

d. Melaksanakan dengar pendapat atau pertemuan dengan instansi yang berwenang melakukan pemberantasan tindak pidana korupsi;

e. Memintak laporan instansi terkait mengenai pencegahan tindak pidana korupsi;

f. Wewenang lainnya sebagaimana diatur dalam Pasal 12, 13, dan 14 UndangUndang Nomor 30 Tahun 2002.

Keberadaan lembaga negara ada yang tercantum dalam UUD 1945 dan ada pula yang dibentuk berdasarkan Undang-Undang serta ada juga yang berdasarkan Keptusan Presiden. Untuk lembaga Komisi Pemberantas Korupsi sendiri merupakan lembaga yang dibentuk berdasarkan Undang-Undang, namun secara kelembagaannya KPK secara yuridis adalah sah berdasarkan konstitusi dan secara sosiologis telah menjadi kebutuhan bangsa dan Negara Republik Indonesia. ${ }^{17}$

\section{Kedudukan Lembaga Komisi Pemberantasan Korupsi Dalam Hukum Islam}

17 Tjokorda Gde Indraputra, I Nyoman Bagiastra, Kedudukan Komisi Pemberantas Korupsi Sebagai Lembaga Negara Bantu (State Auxiliary), Fakultas Hukum Tata Negara Fakultas Hukum Universitas Udayana, h. 4
Korupsi saat ini bisa dikatagorikan persoalan yang kursial, artinya tergolong perbuatan yang membahayakan bagi kebutuhan hidup manusia (dharuri/primer). Kebutuhan dharuri/primer merupakan kebutuhan yang bersifat esesial dan harus dijaga. Menurut Abu Zaharah bahwa kebutuhan ini harus direalisasikan karena akan berbahaya (mafsadah) bila tidak dijalankan bagi manusia. ${ }^{18}$ Sebab dharuri ini mencangkup pemeliharaan agama, jiwa, akal, keturunan dan harta.

Selain kemaslahatan, terdapat mahsadah yang dibagi dua, menurut Izzuddin bin Abdis Salam (seperti diikutip Abu Zahra), yaitu mafsadat yang diharamkan oleh Allah untuk didekati dan mafsadah yang tidak disukai oleh Allah (makruh) untuk dikerjakan. Abu Zahrah menambahkan bila suatu perbuatan haram mafsadahnya lebih banyak, maka tingkat keharamannya lebih tinggi.

Perjalanan sejarah kekuasaan kehakiman dalam Islam menunjukkan bahwa kekuasaan yudikatif yang sudah dilaksanakan oleh beberapa lembaga yang masing-masing berkuasa dalam bidangnya, tetapi bersatu di bawah satu kekuasaan umum. Pada dinasti Umayyah, kekuasaan kehakiman menyebutnya lembaga pelaksana hukum (Nizam al-Qadha'), sedangkan pada masa Dinasti Abbasiyah menyebutnya lembaga yang bertugas memberi

18 Muhammad Abu Zahra, Ushul Fiqh, (Jakarta: Pustaka Pirdaus, 2003), h. 533 
Yopa Puspitasari:

Kedudukan Komisi Pemberantasan Korupsi (KPK) Dalam Struktur Ketatanegaraan Indonesia Ditinjau Dari

Hukum Islam

penerangan dan pembinaan hukum (Nizham al-Mazhalim). ${ }^{19}$

Di dalam Islam tidak ditemukan lembaga independen seperti Komisi Pemberantasan Korupsi, namun secara sekilas, tugas dan wewenang Wilayah Al-Mazhalim, ada kemiripan dengan Komisi Pemberantasan Korupsi, walaupun Wilaya Mazhalim lebi luas tidak hanya persoalan Korupsi.

Wilaya Al-Mazhalim merupakan suatu lembaga peradilan independen untuk menyelesiakan peselisihan antara rakyat dan pemerintah yang kekuasaannya dalam bidang Peradilan lebih tinggi dari pada Hakim dan Mah'tasb. Selain itu, lembaga Al-Madzhalim adalah lembaga yang menangani masalahmasalah yang diluar kewenangan Hakim biasa. Salah satu tugas lembaga ini yaitu, memeriksa perkara-perkara penganiayaan yang dilakukan oleh Penguasa-penguasa dan Hakim-hakim ataupun anak-anak dari penguasa. Kewenangan dari Wilayah Al-Mazhalim adalah yang pertama mengawasi tingkah laku penguasa dan keluarganya, serta mencegah kemungkinan pelanggaran serta ketidak jujuran, kedua memeriksa dan menganalisa kecurangan pejabat dan pegawai yang bertanggung jawab atas pungutan uang Negara, ketiga mengembalikan hak-hak rakyat

${ }^{19}$ Jaenal Arifin, Peradilan Agama Dalam Bingkai Reformasi Hukum di Indonesia, (Cet 1, Jakarta: Fajar Interpratama Ofset, 2008), h. 170 yang diambil secara melawan Hukum baik oleh pejabat Negara maupun orang lain yang selalu memaksa kehendaknya. ${ }^{20}$

Seperti yang kita ketahui bahwa Wilayah al-Mazalim merupakan suatu kekuasaan yeng lebih tinggi dari Wilayah alQadha' dan Wilayah Hisbah, yakni untuk menyelesaikan perkara-perkara yang tidak bias diselesaikan oleh kedua lembaga tersebut, misalnya masalah penganiayaan yang dilakukan oleh penguasa, hakim-hakim,atau keluarganya.

\section{- Dasar Hukum Pembentukan Wilayah} Al-Mazhalim

Seperti yang tertera di beberapa bagian kandungan ayat Al-Qur'an, keberadaan Wilayah Al-Mazhalim terdapat dalam Surah Al-Baqarah ayat 279 dan Surah As-Syura' ayat 40-42, serta kandung Hadist.

Qadha' Mazhalim yaitu salah satu jenis peradilan yang secara khusus bertugas menyelesaikan perkara yang melibatkan pejabat atau keluarga pejabat negara. Selain itu dalam sejarah Rasulullah SAW, pernah menyelesaikan suatu perkara pidana kasus air minum antara Zubair Ibn Awam dengan seorang laki-laki dari kaum Anshar dan beliau berindak sebagai Qadh Mazhalim. ${ }^{21}$

20 Jurnal Al-Ulum, Kekuasaan Kehakimandalam Islam Dan Aplikasinya Di Indonesia. (volume 13 Nomor 2, Desember 2013), h. 444-445

21 Oyo Sunaryo Mukhlas, Perkembangan Peradilan Islam, (Bogor: Penerbit Ghalia Indonesia, 2011), h. 28 
Pada awalnya, sebelum perkara ini diketahui, dan diselesaikan Rasulullah, pihak penggugat (laki-laki Anshar) memiliki beban pesikologi yang cukup berat, seakan-akan sudah kalah sebelum bertanding" mengingat posisi lawannya, Zubair Ibn Awwam adalah keluarga dekat Rasulullah. Tetapi ia menyadari apabilah perkara tersebut tidak segera diselesaikan ia akan merasa sebagai pihak yang teraniayah oleh Zubair Ibn Awwam. Sangat beruntung, karena Rasulullah mengetahui persoalan yang tengah dihadapi oleh laki-laki Anshar itu. Dalam perkara ini Rasulullah memutuskan dengan adil, tanpa memilih-milih dan memihak satu pihak. ${ }^{22}$

Tindak Rasulullah tersebut dapat disimpulkan bahwa dalam menyelesaikan perkara beliau memberikan landasan bahwa selain Wilayah Al-Qadha' sebagai lembaga peradilan negara yang permanen, dapat pula dibentuk lembaga peradilan luar biasa, yang bersifat incidental. Praktik peradilan yang sejenis dengan Qhadi' Mazalim banyak dikenal diberbagai wilayah negara Islam dan negara muslim.

\section{- Tugas Wilayah Al-Mazalim}

Tugas Wilayah Al-Mazalim menurut Al Mawardi di dalam bukunya Al-Ahkamu Sultaniyah menerangkan bahwh perkara-

22 Su'ud Ibn Sa'ad al-Darib, Al-Tanzhim alQadha'iyy fi al-Mumlakat al-Arabiyah al-Su'udiyah, (Riyadh: Maktabat al-Wazir, 1983), h. 179-177 perkara yang diperiksa oleh lembaga ini ada 10 macam: $^{23}$

1. Menyelesaikan perkara pelanggaran hukum dan segalah bentuk penyimpangan yang dilakukan oleh pejabat kepada rakyatnya pada saat berkuasa.

2. Memeriksa Segalah bentuk kecurangan para petugas dalam menjalankan tugasnya saat penarik zakat atau pajak.

3. Memeriksa hasil kerja para penulis dokumen, karena mereka merupakan orang-orang yang dipercaya kaum muslim untuk mencatat hak mereka dalam harta mereka

4. Melakukan penyelidikan terhadap pelanggaran hukum (kedzaliman) terhadap pegawai, misalnya gaji kurang dan pembayarannya tertunda.

5. Harta rampasan yang diambil harus dikembalikan kepada pemiliknya.

6. Menangani harta wakaf, yang terbagi antara wakaf khusus dan umum.

7. Mengeksekusi terdakwa yang tidak dapat dihukum atau terdakwa tersebut merupakan orang terhormat yang takut untuk di eksekusi.

8. Menangani kepentingan umum yang tidak bias diselesaikan oleh para muhtasbih (petugas hisbah), misalnya mereka terangterangan mengerjakan kemungkaran yang

\footnotetext{
${ }^{23}$ Imam Al-Mawardi,Al-Hakam AsSulthaniyyah (Hukum-Hukum Penyelenggaraan Negara dalam Syariat Islam), terj. Fadli Bahri, (Bekasi: PT Darul Falah; 2017), h. 147-152
} 
Yopa Puspitasari: Kedudukan Komisi Pemberantasan Korupsi (KPK) Dalam Struktur Ketatanegaraan Indonesia Ditinjau Dari Hukum Islam

terang-terangan dan petugas hisbah tidak mampu menyelesaikannya.

9. Mengawasi pelaksanaan ibadah-ibadah, misalnya sholat Jumat, sholat hari raya, jihad dan haji.

10. Memberikan putusan hukum kepada pihak-pihak yang berpekara.

Adapun tugas Wilayah Al-Mazalim yang mempunyai kesamaan dengan lembaga independen Komisi Pemberantasan Korupsi yang berada di Indonesia antara lain:

1. Kecurangan pegawai-pegawai yang ditugaskan untuk mengumpulkan zakat dan harta-harta kekayaan negara yang lain.

Wilayah Al-Mazalim bertugas mengirim utusan agar mengirim utusan untuk menyelidiki hasil pengumpulan pajak dan harta, serta memerintahkan kepada para pegawai yang bertugas tersebut untuk mengembalikan kelebihan penarikan harta dan pajak/zakat kepada pemiliknya. Dari tugas diatas dapat disimpulkan bahwa wilayah Al-Mazalim hampir sama dengan kewenangan dari KPK yang ada di Indonesia karena jika terjadi kecurangan pegawai-pegawai yang ditugaskan untuk mengumpulan zakat dan harta-harta kekayaan negara lain maka yang menangani persoalan itu adalah Wilayah Al-Mazalim, selain itu peradilan ini bertujuan untuk mengembalikan hak-hak rakyat yang telah diambil oleh mereka, serta untuk menyelesaikan persengketaan antara penguasa dan warga negara.

2. Mengontrol/mengawasi keadaan para pejabat,

Wilayah Al-Mazalim bertugas untuk mengontrol/mengawasi keadaan para pejab, karena jika terjadi kecurangan atau dicurigai melakukan suatu kecurangan maka Wilayah AlMazalim berhak untuk mengontrol/mengawasi keadaan pejabat yang dicurigai tersebut. Para pegawai kantor pemeritahan harus amanah karena umat islam mempercayakan kepada mereka masalah harta benda. Serta Nadir AlMazalim adalah untuk meneliti tingka laku dan menghukum mereka berdasarkan Undang-Undang yang berlaku.

3. Pengaduan yang diajukan oleh tentara yang digaji lantaran gaji mereka dikurangi atau dilambatkan pembayaran.

Wilayah Al-Mazalim bertugas untuk menampung dan memproses pengaduan yang diajukan atas kezaliman yang dilakukan aparat pemberi gaji kepada orang yang berhak menerima gaji. Ketika gaji tersebut 
tidak diberikan atau dikurangi, tugas Nadir Al-Mazalim untuk memerintahkan kepada pemerintahan untuk mengembalikan apabila gaji tersebut diambil pemerintah dari harta yang diambil bait al-mal.

4. Mengembalikan pada rakyat hartaharta mereka yang dirampas oleh penguasah yang zalim. Wilayah AlMazalim bertugas untuk mencegah perampasan harta, perampasan harta terbagi menjadi 2 (dua) macam, yaitu:

a. Ghusub al-Shultaniyyah, yaitu perampasan yang dilakukan oleh para gubernur yang zalim, baik karena kecintaannya terhadap harta tersebut atau karena keinginannya untuk menzalimi. Tugas Nadir Al-Mazalim adalah mencegah perbuatan zalim apabila belum dilakukan maka apabila telah dilakukan tergantung dengan pengaduan yang dizalimi tersebut,

b. Perampasan yang dilakukan oleh "orang kuat". Dalam hal ini pemerosesan perkara tergantung kepada pengaduan atau adanya tindak kezaliman dan harta yang dirampas tidak bisa diambil kecuali dengan empat perkara yaitu :

- Pengakuan dari orang yang merampas harta tersebut
- Perampasan tersebut diketahui oleh wali Al-Mazalim dan ia boleh menetapkan hukum berdasarkan pengetahuannya,

- Adanya bukti yang menunjukan dan menguatkan tindak kezaliman tersebut,

- Adanya berita yang kuat tentang kezaliman tersebut.

- Memperhatikan harta-harta wakaf.

5. Wilayah Al-Mazalim bertugas untuk mengawasi/memperhatikan harta wakaf. Harta wakaf terbagi menjadi dua macam, antara lain:

a. Wakaf umum, Nadir Al-Mazalim bertugas untuk mengawasi agar harta wakaf tersebut tidak disalah gunakan, meskipun tidak ada pengaduan tentang adanya penyimpangan,

b. Wakaf Khusus, Nadir Al-Mazalim bertugas untuk memperoses perkara setelah adanya pengaduan mengenai penyimpangan terhadap wakaf tersebut

Dari penjelasan diatas dapat disimpulkan bahwa adanya kesamaan lembaga Komisi Pemberantas Korupsi yang berada di Indonesia, dengan Wilayah Al-Mazalim yang ada di Negara Islam.

Selain itu, Wilayah al-Mazhalim adalah suatu lembaga yang bersifat 
Yopa Puspitasari:

independen, yakni tidak bisa diintervensi oleh kepala negara atau pejabat lainnya. Agar pelaksanaan persidangan kasus mazhalim ini berjalan dengan lancar dan obyektif, dilengkapi 5 (lima) perangkat peradilan $^{24}$, yaitu
a. para hakim dan perangkat kehakiman,
b. para pakar hukum atau fuqaha,
c. panitera,
d. penjaga keamanan atau polisi peradilan, dan
e. para saksi.

\section{Penutup}

Dari permasalahan yang cukup panjang pada artikel ini mengenai kedudukan lembaga Komisi Pemberantasan Korupsi (KPK) dalam sistem ketatanegaraan Indonesia dapat ditarik kesimpulan bahwa kedudukan lembaga Komisi Pemberantasan Korupsi (KPK), tercantum didalam Undang-Undang Nomor 30 Tahun 2002 tentang Komisi Pemberantas Korupsi. Dimana lembaga Komisi Pemberantas Korupsi tersebut bersifat independen dan bebas dari pengaruh atau campur tangan penguasa. Walaupun lembaga Komis Pemberantas Korupsi tersebut diatur diluar Konstitusi, namun kedudukannya hampir sejajar dengan lembaga-lembaga yang diatur dalam Konstitusi.

${ }^{24}$ Lomba Sultan, Kekuasaan Kehakiman Dalam Islam Dan Aplikasinya Di Indonesia, h. 447
Sedengkan dalam Hukum Islam Sendiri tidak ditemukan refrensi yang tepat mengenai lembaga independen seperti Komisi Pemberantas Korupsi, tetapi secara hakikatnya tugas dan wewenang yang dimiliki Wilayah Mazhalim, hampir ada kemiripan dengan Komisi Pemberantas Korupsi, Walaupun Wilayah Mazhalim lebih luas tidak hanya persoalan korupsi. Wilayah Mazhalim adalah lembaga yang suatu kekuasaan dalam bidang peradilan yang lebih tinggi dari pada Hakim dan Mah’tasb.

\section{Pustaka Acuan}

Arifin, Jaenal, 2008."Peradilan Agama Dalam Bingkai Reformasi Hukum Di Indonesia". Cetak 1. Jakarta: Fajar Interpratama Ofset.

Asshiddiqie, Jimlly 2006. Pengantar Ilmu Hukum Tata Negara Jilid 1. Sekretariat Jakarta: Jenderal Dan

Kepaniteraan Mahkamah Konstitusi RI.

Asshiddiqie, Jimlly. 2003.Struktur

Ketatanegaraan Indonesia Setelah perubahan keempat UUD tahun 1945, Denpasar: Badan Pembinaan Hukum Nasional Dapertemen Kehakiman Dan Hak Asasi Manusia RI.

Asshiddiqie, Jimlly. 2006.Perkembangan dan Konsolidasi Lembaga Negara Pasca Reformasi,. Jakarta: Sekretariat Jendral Dan Kepaniteraan Mahkamah Kosntitusi RI.

Danil,Elwi.2012. KORUPSi (Konsep, Tindak Pidana, dan Pemberantasannya, Jakarta: PT Raja Grapindo Persada. Djaja, Ermansjah.2013.Membrantas Korupsi Bersama KPK. Jakarta: Sinar Grafika. 
AL-IMARAH: Jurnal Pemerintahan dan Politik Islam

Vol. 4, No. 2, 2019

Indrayana, Denny. 2008. "Negara Antara Ada Dan Tiada Reformasi Hukum Ketatanegaraan”. Jakarta: Kompas.

Rohmah, E Imeldatur, bab II Kajian Teori. http://digilib.uinsby.ac.id/8699/57/Bab \%202.pdf. Diakses Pada Hari Rabu, 10 Oktober 2019, Pukul 13.53 Wib

Sunaryo Mukhlas, Oyo. 2011. Perkembangan Peradilan Islam. Bogor: Penerbit Ghali Indonesia.

Triwulan Tutik, Titik. 2010. Konstruksi Hukum Tata Negara Indonesia Pasca Amandemen UUD 1945.Jakarta: Kencana Prenada Media Group.

Undang-Undang Nomor 12 Tahun 2011

Tentang Pembentukan Peraturan Perundang-Undangan

Undang-Undang Nomor 30 Tahun 2002 Tentang Komisi Pemberantas Tindak Pidana Korupsi

Undang-Undang Nomor 31 Tahun 1999

Tentang Tindak Pidana Korupsi

UUD NRI Tahun 1945

Wilbawa, Samodra. 2015. Reformasi Administrasi. Yogyakarta: Penerbit Gava Media.

Wilyono. 2012. Perkembangan UndangUndang Pemberantas Tindak Pidana Korupsi. Jakarta: Sinar Grafika. 